\title{
Civil Society and Regional Governance: Knowledge Production and Issue-Framing around SADC
}

\author{
ANDRÉAS GODSÄTER \\ School of Global Studies \\ University of Gothenburg \\ Box 700 \\ 40530 Göteborg \\ Sweden \\ e-mail: andreas.godsater@globalstudies.gu.se \\ Centre for the Study of Governance Innovation \\ Department of Political Sciences \\ University of Pretoria \\ Private Bag X20 \\ Hatfield - 0028 Pretoria \\ South Africa \\ e-mail: andreas.godsater@up.ac.za
}

\begin{abstract}
Scholars have recently begun to study civil society on the regional level more systematically. When regionalization of civil society is studied, it is often understood within processes of regional governance in which state actors craft regional institutions and policy frameworks to solve common problems. Yet, most studies dealing with civil society in regional governance has a statecentric approach, focusing on the marginalization of civil society organizations (CSOs) in such processes, treating them as rather passive actors. This is especially true for research on southern Africa. Contrary to previous studies, this article shows under what circumstances CSOs are granted space in regional policy-making related to the Southern African Development Community (SADC). It is concluded that, in light of CSOs' material and economic weakness, one of the key factors determining their advocacy success on the regional level is production of knowledge and strategic use of communication tools. Even though many challenges remain, for example the power structures inherent in the SADC, the case of civil society advocacy around the SADC is a sign of a new form of participatory regional governance in the making, which is more democratic than present modes of regional governance in Africa.
\end{abstract}

KEY WORDS: Civil society, regional governance, gender, trade, southern Africa

\section{Introduction}

Research on civil society across the world is abundant, especially with regards to the global South where the number of non-governmental organizations (NGOs) has increased dramatically since the 1980 s due to economic liberalization, democratization and the availability of donor funding. This growth has increasingly called the attention of scholars 
(e.g. Dagnino, 2011; Obadare, 2011; Opoku-Mensah, 2008; Tandon \& Kak, 2008). These studies are based on a notion that civil society operates and consolidates on a 'national' basis (i.e. state-civil society interaction at the domestic level). In order to provide a perspective beyond the national government and accommodate contemporary changes in politics and the world order, largely related to globalization, there is also a substantial body of literature investigating various aspects of transnationalization of civil society (e.g. Kaldor, 2003; Katz, 2006; Salamon et al., 2004). A recent focus of this scholarship relates to the increasing influence of civil society organizations (CSOs) in global governance, filling a democratic deficit that has long plagued international institutions (e.g. Fogarty, 2014; Jönsson \& Tallberg, 2010; Scholte, 2011; Tallberg et al., 2013).

Despite the quite expansive research output on transnational civil society, the regional dimension of civil society is on the whole still greatly under-researched. In most studies dealing with civil society across national borders, 'transnational' means 'global'. For civil society scholars, regionalization is a quite new phenomenon to study. The converse is also true; there is a general lack of attention put on civil society in regionalism studies. Only quite recently have scholars begun to study civil society regionalization, which implies a process where people engage in co-operation within diverse types of regionalist civil society frameworks (Farrell, 2005, p. 8) in different parts of the world (e.g. Gilson, 2011 and Igarashi, 2011 on East/Southeast Asia; Grugel, 2006 and Saguier, 2011 on Latin America; Hinds 2008, on the Caribbean; Reuter, 2007 on the Baltic region; Landsberg, 2012 and Söderbaum, 2007 on southern Africa; Godsäter, 2013 and Kimani, 2007 on East Africa). Often, such studies somehow relate to the so-called new regionalism (e.g. Fawcett \& Hurrell, 1995; Hettne, 2005). When the regional dimension of civil society is studied, it is often understood within processes of regional governance in which state actors craft regional institutions and policy frameworks to solve common problems. Yet, such studies generally focus on the marginalization of CSOs in such processes and thus paying little attention to CSOs in their own right. One authoritative scholar in the regionalism field, Luk Van Langenhove, recently concluded that 'the role of civil society in regionalism receives too little systemic analysis and is often ignored' (2011, p. 89).

This tendency is most pronounced in Africa where the role of CSOs in regionalization generally has been greatly underestimated and often ignored, especially in southern Africa. Most of the time scholars dismiss the role of civil society in regional governance, manifested by regional inter-governmental organizations (RIGOs) such as the Southern African Development Community (SADC), as nominal, insignificant and even non-existent (e.g. Landsberg, 2012; Matlosa \& Lotshwao, 2010; Peters-Berries, 2010; Pressend, 2010; van der Vleuten \& Hulse, 2013). Furthermore, when the role of CSOs in regional policy-making is occasionally given attention, scholars do not dwell on why CSOs are, or are not, successful in their regional advocacy efforts.

This article challenges the pessimistic and empirically thin approach to the study of civil society regionalization in southern Africa ${ }^{1}$ and elsewhere. Based on new empirical data ${ }^{2}$ it will be shown that southern African civil society actors can be influential at the regional level in relation to regional state actors. More specifically, the article discusses the ways in which the extent of this influence is linked to the success of CSOs in two particular areas: knowledge possession and issue-framing. This article will show that, in light of CSOs' material and economic weakness, one of the key factors determining CSOs' potential to affect policy on the regional level is possession of knowledge and strategic use of communication tools, using what one scholar calls the power of persuasion (Korey, 1999). How proposals for policy change are communicated, by whom and for what purpose determine the success of getting the attention of RIGOs such as SADC. In particular, the ability to produce knowledge and communicate policy claims in ways that get the attention of policy-makers is essential for 
CSOs to gain policy influence (Risse, 2002). The article speaks to both civil society studies, adding knowledge about civil society on the regional level, and studies on regional governance, investigating the role of civil society. It will be argued that the case of civil society advocacy around SADC is another example of the evolution of a new form of regional governance in Africa: participatory regional governance (see Godsäter, 2013 with regards to regional environmental governance in East Africa ).

The article focuses on three regionally active CSOs: SADC Council of NGOs (SADCCNGO), Southern African People's Solidarity Network (SAPSN) and Gender Links (GL). Based in Botswana, SADC-CNGO is a regional civil society umbrella organization with national networks of NGOs from all SADC countries as members, which seeks to influence development policies in SADC (SADC-CNGO, 2009). Based in Malawi, SAPSN is a regional network which unites a broad range of CSOs and institutions, including trade unions, development NGOs, church-based social organizations and community-based movements in the quest for social justice (SAPSN, 2009). Finally GL, based in South Africa, is a regional NGO, which urges national and regional policy-makers to protect women's rights (GL, 2009).

The remainder of the article is divided in four parts. First, civil society and regional governance will be conceptualized and the concepts of knowledge possession and issue framing will be discussed. A general discussion of civil society and the state in southern Africa follows. The main empirical section then analyses CSO advocacy in SADC with regards to knowledge possession, issue-framing, and power structures. A conclusion rounds up the article.

\section{Civil society and regional governance: conceptual considerations}

There is a rich variety of definitions and meanings of 'civil society' (Muukkonen, 2009; Scholte, 2005), but some common denominators can be distilled. Civil society is often loosely defined as the public realm and the associational life existing between the state and the private sector. From this perspective civil society is seen as an arena where different associations can express their interests and engage with the state (e.g. Scholte, 2005; Söderbaum, 2007). Furthermore, influenced by liberal thinking, the mainstream view of civil society is often conceptualized as open and autonomous, engaging in constructive dialogue with the state for the mutual benefit of society as a whole (Edwards, 2009, p. 24). The latter view is challenged here. Civil society is rather seen as a heterogeneous field of different and sometimes conflicting views and functions (Dagnino, 2011), including competing roles in regional governance. Therefore, civil society actors may be involved in complex, rather than simple and straightforward, relationships with different types of state and market actors, as will be evident by the example of SADC.

Moving on, since the nation-state is being reorganized in a time of globalization, and non-state actors, including CSOs, have assumed many responsibilities and functions traditionally reserved for the state, there is a need to think in terms of more complex and multilevel modes of governance, instead of (national) government (Söderbaum, 2004). Governance denotes rules, structures and processes providing some measure of regulation, by various actors, over specific areas of activity and working towards certain objectives (Armstrong \& Gilson, 2011, p. 1). To put the concept of governance in a broader perspective, it is normally used in three contexts. First, international governance relates to a process where the prime actors are states and the objectives relate to the regulation of interstate relations. Second, global governance involves state, intergovernmental and non-state actors since it is concerned with the regulation of broad areas of interaction. Thirdly, regional governance is a 
subset of global governance involving state, interstate and non-state actors, which is applicable to a specific region (Armstrong \& Gilson, 2011, pp. 2-3)

Söderbaum (2004) has conceptualized two variants of regional governance in Africa: sovereignty-boosting and neoliberal. In sovereignty-boosting regional governance, political leaders use regional governance to strengthen the sovereignty of the state. This means signing various regional documents with the purpose of praising the values of regionalism, which in turn enables political leaders to increase legitimacy for their regimes (Söderbaum, 2004, pp. 425-426). Neoliberal regional governance emphasizes regional economic integration which is market-driven. The welfare ambitions of the state are side-lined, and poverty reduction is limited to economic growth in which development projects must be profitable. The role of regional institutions is to facilitate trade through liberalization schemes (Söderbaum, 2004, p. $423,425)$. Both types of regional governance are highly applicable to SADC, as will be shown below.

The involvement of CSOs in regional governance is partly determined by state actors such as SADC. ${ }^{3}$ However, within the given (constraining) context of sovereignty-boosting and neoliberal regional governance, CSOs have the possibility to affect the success of engaging with the SADC, laying the foundation for a new form of regional governance, referred to as participatory regional governance (Godsäter, 2013). In this type of regional governance, it is argued, CSOs are at least partly involved in regional policy-making and service provision. This creates a certain level of legitimacy for RIGOs since state actors in participatory regional governance schemes are somehow accountable to public actors, or at least pushed to increase accountability. This newly emerging type of regional governance is more democratic and development-oriented (Godsäter, 2013).

According to social constructivist studies on social movements and transnationalization of civil society, ideational factors such as identity, knowledge and communication strategies are important in order to understand how and why actors emerge, take certain kinds of action and have policy impact (e.g. Keck \& Sikkink, 1998; Risse, 2002). In terms of policy impact, civil society actors can pressure states to act in new ways and shape international policy since the identities, ideas and interests of state actors are not fixed or given but are socially constructed and therefore prone to change over time (Chandler, 2004, p. 19). Hence, the materially more powerful actors (states) do not necessarily control the better arguments and materially weaker ones (CSOs) can achieve considerable policy-making success by using ideational resources (Risse, 2004).

The power to affect policy is linked to the type of knowledge that an organization produces. Two aspects are crucial: expertise and experiential evidence. Expertise is often related to rarity, i.e. unique knowledge about a specific issue, and therefore often referred to as technical expertise, which in turn often draws from the legitimacy of the academic and political world (Van Rooy, 2004, p. 81). Experiential evidence, on the other hand, draws from the legitimacy of the grassroots. Organizations with close links to the field derive their knowledge from direct experience of people's own understanding of poverty, gender inequality, environmental problems and other issues (Van Rooy, 2004, p. 92).

That knowledge needs to be communicated. In order to persuade policy-makers to make policy reforms, policy demands have to be framed in a thoughtful way (Risse, 2002, p. 268). Issue-framing refers to how CSOs render events or occurrences meaningful to their target groups (such as SADC), members and partners by organizing experiences and guiding action in a certain pedagogical and sometimes provocative way (Keck \& Sikkink, 1998). Issue-framing is often linked to some sort of injustice in the sense that moral indignation is felt over something. This implies that the source of feelings of injustice are linked to clearly identifiable targets, such as states, a group of states (such as SADC) or corporations, who are accused of bringing harm and suffering to some part of the population (e.g., poor people, 
women or workers) and have the power to make a change (Gamson, 1995, pp. 90-92). Hence, issue-framing can be adversarial, but not necessarily so. Issues can also be consciously framed in ways that resonate with the agendas of the target groups in order to gain entry to policymaking circles. Often, issue-framing is codified in resolutions and other existing policy frameworks (van Rooy, 2004, pp. 95-97). This can be manifested in so-called 'shaming', whereby CSOs remind state actors of their obligations and demand that they live up to certain norms and/or implement policies and programs. Hence, an important dimension of issueframing is linked to moral authority, i.e. the ability to make policy demands in terms of some commonly recognized social values (Risse, 2002, p. 268).

To summarize, knowledge possession and issue-framing are generally important instruments for civil society to influence policy. By discussing CSO advocacy around SADC, the empirical sections will show how this is played out on a regional level. But before that, the more general scene in southern Africa will be introduced.

\section{Civil society and the state in southern Africa - general trends}

In southern Africa, many states have fostered a regional political culture of authoritarian rule and the dominance of personal rulers is strong (Peters, 2011, p. 165). In some cases, so-called neo-patrimonial, rent-seeking political elites use the 'democratic' state for enriching themselves (Söderbaum \& Taylor, 2008). This state-centrism has greatly influenced state-civil society relations, to the detriment of CSOs. Many governments in the region, for example in Zimbabwe, Namibia and Mozambique, have an innate distrust of civil society and often undermine its ability to play a meaningful role in democracy and development. Therefore, a number of SADC member states do not welcome collaboration with CSOs (e.g. FDC, 2007; Michael, 2004; Ndumbaro \& Kiondo, 2007; Sachikonye, 2007).

The above has great repercussions on the regional level. Regional integration in southern Africa has historically been the preserve of states and governing elites, and popular participation in regional integration frameworks has been very weak (Tsie, 2001, p. 132). $\mathrm{SADC}$, as the current main manifestation of regionalism in southern Africa, is deeply statecentric and elite-driven (Matlosa \& Lotshwao, 2010, p. 52). To a large extent, decisionmaking power is centralized in the heads of state and government at the annual SADC Summit (Matlosa \& Lotshwao, 2010, p. 46). Even though members have formally ceded some policy-making powers to a few SADC institutions, such as the Secretariat, SADC's administrative and executive organ, in reality these institutions have no real authority (Afadameh-Adeyemi \& Kalula, 2011). Since the overriding motivation for regional governance in southern Africa is for leaders to exert national interests and strengthen the regimes, SADC is a good example of sovereignty-boosting regional governance.

SADC is largely driven by power politics and logically does not voluntarily give up that power to the benefit of CSOs. It is widely recognized by civil society and academic commentators, as well as SADC officials, that civil society is generally deliberately marginalized in SADC-led regionalism and that consultation with CSOs in most sectors is minimal. ${ }^{4}$ According to two scholars, ' $[\mathrm{t}]$ he integration agenda still remains state-centric, elite-dominated and exclusionary. Ordinary people still remain objects, and not subjects, in a regional project ostensibly aimed at improving their lives' (Matlosa \& Lotshwao, 2010, p. 49).

Besides statism, the neoliberal discourse has made a substantial imprint on social order in Africa (Harrison, 2010). Neoliberal reforms have taken place in almost all countries in southern Africa and trade liberalization, privatization of national assets, commodification of social services and marketization of goods have become intrinsic in policy-making. The 
prevailing neoliberal discourse has paved the way for NGOs to take the place of the state in service provision (Dibie, 2008, p. 2). In most regards, NGOs buy into the mainstream problem-solving agenda inherent in the prevailing global neoliberal ideology, in which development problems inherent in the dysfunction of the social order, such as lack of services and the malfunction of certain political structures and markets, are to be 'solved' by stateNGO partnership. Hence, civil society in southern Africa is focusing more on meeting immediate societal needs than on having political functions in terms of influencing the overall policy environment on a deeper, structural level (Opoku-Mensah, 2008). This is specifically evident in states such as Tanzania and Mozambique (e.g. FDC, 2007; Michael, 2004; Ndumbaro \& Kiondo, 2007). The dynamics of the neoliberal social order have also created critical NGOs and social movements that challenge government policy in some states in southern Africa, such as South Africa and Zimbabwe, for example in terms of the privatization of water and market-based land reform. These movements also demand improved public service delivery. Often, contentious strategies such as demonstrations and civil disobedience are used outside of the accepted ways of interacting with the state. These actors are often seen as enemies by the state and marginalized in policy discussions (Ranchod, 2007).

At a regional level, the neoliberal agenda is so entrenched within SADC that '...rarely are the nature of free trade and its assumptions challenged' (Pressend, 2010). Regional governance is in many regards neoliberal. SADC views business as particularly important in the process of regional integration (Matlosa, 2006, pp. 7-8), for example in building infrastructure and job creation (Blaauw, 2007, p. 205). Of the regional CSOs associated with SADC, the majority are business related.

However, SADC has also designed some corrective measures to mitigate the negative consequences of economic integration for poor people (Kanyenze, Kondo \& Martens, 2006) such as the spread of HIV/AIDS, environmental degradation and the informalization of the economy. Therefore, policy-making and implementation of regional programs related to HIV/AIDS, gender and the protection of workers' rights involve collaboration with certain service-providing and research NGOs active in these areas. Such CSOs engage with regional interstate frameworks on a consultative basis, mainly in order to solve joint problems related to, for example, policy development and the lack of social services.

\section{Civil society advocacy around SADC: influencing policy through good arguments}

Through the case of CSO advocacy around SADC, the conditions for civil society policy influence on a regional level will now be discussed. It will be shown that possession of knowledge and how knowledge is framed and policy proposals communicated are vital for influencing SADC-led regional governance. Regional policy influence varies between the three CSOs according to the knowledge and moral authority they each possess. Power structures also play an important role in this regard.

\section{Knowledge production}

In order to be included in regional governance in SADC and have policy influence, CSOs need to be knowledgeable and well-informed about the issues they deal with; support their policy claims with evidence from the grassroots level; and present viable policy alternatives. This is a common observation among scholars, donors and policy-makers acquainted with regional civil society in southern Africa. ${ }^{5}$ According to one commentator, 'if you talk to 
SADC and don't know what you are saying, then they dismiss you immediately. But if you go there well-prepared with your analysis and documents and you articulate the issues in a way that they can really appreciate, then I think this is a source of power for civil society' ${ }^{6}$ This is true of GL, but less so with regards to SADC-CNGO and SAPSN, as discussed below.

At first glance, SADC-CNGO has great qualifications for policy influence in SADC. It has been singled out by SADC as a key civil society partner representing NGOs in the region. ${ }^{7}$ The relationship between the two is institutionalized in a Memorandum of Understanding (MoU), which provides a framework for cooperation for the implementation of the SADC agenda (SADC-CNGO, 2003). However, the partnership between SADC-CNGO and SADC is deeply problematic. In fact, it '...exists in the world of theory. It has not yet been translated into practical reality' (Matlosa \& Lotshwao, 2010, p. 41). There is no formal consultative process between SADC and SADC-CNGO, and the space for real policy influence is narrow. For example, SADC-CNGO does not have an effective and regular space to critically influence the SADC Summit. ${ }^{8}$ One important reason behind the marginalization of SADC-CNGO is related to its weak knowledge about trade and development issues. ${ }^{9}$ When SADC-CNGO is invited to SADC meetings it does not use that opportunity to influence: 'They merely sit there, and are happy with that, but don't contribute with substance. And, SADC knows that these RCSOs will not make a difference in policy-making, nor participate significantly in implementation of programs'. ${ }^{10}$ SADC-CNGO also struggles to document evidence from local realities in its advocacy work. ${ }^{11}$ The people participating at the SADC Civil Society Forum, an annual regional event founded by SADC-CNGO and organised by the coalition together with partners parallel to the SADC Summit, are normally not the ones working directly with the issues discussed, nor do they have grassroots experience. Also, when called on by the SADC Secretariat to discuss trade issues such as Economic Partnership Agreements between SADC countries and the EU, SADC-CNGO does not send experts from the various member NGOs, but sends rather staff from its own regional office who know very little about the issues. ${ }^{12}$ SADC-CNGO confesses that for regional civil society at large, ' $[\mathrm{s}]$ ome of the $[\ldots]$ policy demands tend to be overly general and predictable and of little practical value for regional policy formulation' (SADC-CNGO, 2010, p. 11). All in all, SADC-CNGO has not managed to make serious inroads into the regional agenda and remains highly ineffective (Landsberg, 2012).

SAPSN also has difficulties gaining the ear of SADC, partly due to the use of radical advocacy methods but also because of SAPSN's lack of issue substance. According to one former SADC representative, SAPSN struggles to provide viable alternatives to the current regional agenda that are based on evidence when it delivers criticism. ${ }^{13}$ This is related to its general lack of knowledge of current development processes in the region. In various statements such as Peoples' Declarations issued at the Peoples' Summit, another more critical civil society meeting parallel to the SADC Summit, SAPSN offers rather sweeping comments on a new regionalist agenda, but no concrete programs for this people-driven regionalism. ${ }^{14}$ SAPSN itself agrees that 'making noise' at Peoples' Summits in terms of demonstrations and marching must be matched with serious proposals for change, which is currently lacking. ${ }^{15}$

Particularly CSOs dealing with social justice and human rights issues, such as SADCCNGO and SAPSN, have difficulty gaining policy influence in SADC. However, other types of CSOs, including some business-related and think thank organizations, have managed to participate in regional policy-making. Their advocacy success can be partly explained by their ability to produce well-researched, evidence-based knowledge that is sought after by SADC. This ability also applies to CSOs in the gender area. The relative success of gender mainstreaming in SADC can partly be attributed to the demand from highly active civil society groups on a regional level (van der Vleuten \& Hulse, 2013), coupled with an openness on behalf of SADC to give CSOs an opportunity to express their concerns due to a need for 
human resources in the gender field (Debusscher \& Hulse, 2014). One important example is the effective regional advocacy around SADC's Gender and Development Protocol (Landsberg, 2012), a regional legal instrument signed in 2008 which obliges member states to ensure equal rights for women across a range of issues (van der Vleuten \& Hulse, 2013). The so-called Southern Africa Gender Protocol Alliance, a regional coalition of 26 CSOs coordinated by GL, played a key role in the drafting and eventual signing of the Gender Protocol after several months of intense lobbying (van der Vleuten \& Hulse, 2013; Zongwe, 2008; Mukute \& Taylor, 2013). The argument here is that the policy success of GL and partners partly relates to their knowledge production and moral authority in the gender field.

In contrast to SADC-CNGO and SAPSN, GL is widely acclaimed for its expertise in the gender field (e.g. Landsberg, 2012; van der Vleuten \& Hulse, 2013; Zongwe, 2008; Mukute \& Taylor, 2013). Because of this reputation, it has managed to collaborate with most governments in the region as well as SADC (Gender Links, 2014). According to the GL representative, 'we don't go ra-ra-ra; you know women are unequal in the region. We go women are unequal in all of these areas and in all of these countries because of these different reasons'. ${ }^{16}$ In advocating for a SADC Gender Protocol, GL was instrumental in knowledge production within the campaign. For example, GL and partners created a knowledge bank of gender and HIV/AIDS issues in the region and shared it with the SADC Secretariat. GL's policy demands were rooted in the voices and perspectives of grassroots women in the region, obtained through various studies (Gender Links, 2009) and based on experiential evidence. Because of their expertise, GL and partners were given space in various policy-making arenas related to the Protocol process. For example, GL and partners worked closely with the Gender Unit at the SADC Secretariat in the drafting of the protocol, fed the Unit expert information, and participated in the joint SADC-civil society regional task force put together to direct the Protocol process. According to one former SADC representative, GL is the most effective and influential civil society group in terms of engaging SADC because '...they are wellarticulated... and put the issues on the table...[Therefore,]...the new Gender Protocol is as much the product of GL as SADC'. ${ }^{17}$ Similarly, the director of the Gender Unit claims that GL is a good example of progressive NGOs that know what they are doing and add value to regional policy-making in the gender area. ${ }^{18}$

\section{Issue-framing}

In addition to substantial arguments, CSOs also need strategic and well-developed communication devices so that the message reaches its destination and is more likely to influence policy on the regional SADC-level. Framing arguments in ways that relate to a clearly identifiable target based on morally convincing arguments is particularly important in this regard. All three CSOs in this study have defined SADC as well as its various institutions as a key player in regional development, responsible for the well-being of the people in the region, and therefore an important advocacy target. According to one interviewee, "what makes... regional formations powerful is that they have clear targets and enemies in what they are doing, for example, the SADC secretariat, ${ }^{19}$.

Clearly SADC-CNGO puts a lot of effort into aligning its goals with the SADC framework in order to establish contact with SADC. The Coalition's perception of regional integration, development and trade revolves around SADC, and most activities have some link to the SADC agenda (SADC-CNGO, 2009). This is also evident when considering the SADC Civil Society Forum, in which SADC-CNGO has great influence. For example, the forum calls on governments to further implement the SADC Trade Protocol (Pressend, 2010), which laid the foundation for the SADC Free Trade Area launched in 2008. However, despite 
SADC-CNGO's efforts to align itself with the SADC agenda, SADC-CNGO is still largely excluded from various policy-making forums in SADC, particularly in the trade sector. For example, the interaction with the Directorate for Trade, Industry, Finance, Mining and Investment at the Secretariat is very weak. ${ }^{20}$ Also, civil society mobilization around the Summit, led by SADC-CNGO, has had very little effect on the outcomes: 'Forum Declarations and communiqués [...] have [...] had very minimal impact on SADC Policy decisions' (SADC-CNGO, 2010 p. 11). One reason behind this exclusion and lack of effectiveness is SADC-CNGO's failure to argue for its cause in morally convincing terms. SADC-CNGO policy documents reveal that the coalition fails to link policy proposals with feelings of injustice on behalf of certain social groups and is, unlike GL below, not acquainted enough with various SADC policy documents and decisions to successfully shame SADC for not living up to its commitments. Delivering sweeping comments about the need to accelerate implementation of SADC programs or abstract demands for regional integration to be more 'people-driven' (SADC-CNGO, 2011) is not enough to hit regional policy makers' moral spots.

As with SADC-CNGO, many of SAPSN's activities revolve around SADC; not in tandem with the SADC agenda, as is the case of SADC-CNGO, but rather in reaction against it. The framing of SADC as a target for civil society advocacy takes more radical forms since SADC is viewed as an enemy which should be resisted (SAPSN, 2009). In contrast to SADCCNGO, SAPSN bases its advocacy demands on moral grounds, urging SADC leaders to take responsibility for development based on common principles of social justice and equality. ${ }^{21}$ For example, SAPSN claims that the privatization of basic public services, promoted by the SADC neoliberal agenda, violates the right to life because it goes against human rights (SAPSN, 2009). The construction of the SADC as an enemy and moralization of its agenda have indeed consolidated the SAPSN movement and created a regional advocacy momentum. However, the demands often fall on deaf ears. This partly has to do with SAPSN's anticapitalist message, discussed in the next section, but also the choice of methods for communicating that message. SAPSN's version of shaming has been taken too far and become counterproductive. The radical slogans used during SAPSN marches connected to the Peoples' Summit and the ridiculing of political leaders in seminars scare off SADC officials. Regardless of what it has to say, SAPSN is brushed away because, according to one former SADC representative, 'they are insulting [...] If you come to insult the Heads of State in the meeting, do you think they are going to listen? [...] They need to refine their tactics'. ${ }^{22}$

Similar to SADC-CNGO and SAPSN, GL also relates much of its work to the SADC agenda, which helps the organization to gain an entry point to the SADC Secretariat and achieve policy influence. Recognizing SADC's achievements in the gender area, one of GL's key objectives is to '...ensure that SADC remains at the cutting edge of global efforts to ensure voice, choice and control for women' (Gender Links, 2014, pp. 13-14). Therefore, all GL programs are geared towards the SADC Gender Protocol in order to contribute to the realization of all its objectives. GL also tries to push the SADC members to implement the Gender Protocol through GL's Gender Barometer project (Gender Links, 2013). GL's working method - and thus level of success - is quite different in comparison to those of SADC-CNGO and SAPSN. The Gender Protocol campaign and the subsequent Gender Barometer project are excellent examples of these differences. Unlike SAPSN, GL has managed to 'refine its tactics'. One essential factor behind GL's ability to convince the SADC leaders of the importance of a Gender Protocol was its relatively sophisticated effort to shame SADC for not practicing what it preaches. For example, GL highlighted the failure of SADC to comply with various global and regional norms in the gender field (van der Vleuten \& Hulse, 2013) and the difference between member states' existing gender policies and their (poor) implementation (Gender Links, 2009. p. 42). GL also pointed to various SADC 
initiatives to establish the Protocol but which had so far failed to materialize. According to GL own assessment (Gender Links, 2009, p. 34), its way of communicating knowledge and policy demands ' $[\ldots]$ provided the moral and political tools needed to push through a halfopen door'. Furthermore, an important distinction between GL's pragmatic approach and SAPSN's contentious advocacy style is the different use of language. Instead of mocking SADC leaders for not delivering on gender issues (SAPSN style), GL and its partners learned to talk to senior policy-makers in various SADC decision-making bodies during the drafting process in ways that made them listen. On the whole, GL managed to frame gender issues and persuade government representatives, using morally convincing arguments based on expertise and experiential evidence, which played a big role in the development of the Gender Protocol. In recognition for its contribution to the Gender Protocol process, the African Union bestowed an award on GL for being an outstanding CSO promoting the rights of African women (Gender Links, 2014).

\section{Inclusion and exclusion in SADC}

All things being equal in terms of knowledge possession and moral authority, all CSOs do not have equal chances to participate in SADC affairs. Regardless of how well CSOs use such non-material resources in their quest to influence the SADC, the dominating sovereigntyboosting and neoliberal type of regional governance prevents CSOs from participating on equal terms

To start with, regulatory obstacles make it difficult for anyone who wants to engage with SADC on a more formal level to do so. Formal engagements with SADC are regulated by MoUs and contracts, which are limited to a few CSOs that are considered key representatives of civil society and business in the region and/or as possessing valuable policy-related knowledge. Given the Secretariat's limited capacity and a reluctance to talk to those CSOs that challenge SADC's neoliberal agenda, it is efficient and convenient for SADC to single out a limited number of civil society partners. According to one former SADC representative, '...it is impossible for other actors to come in, regardless of how important they are...The only interaction is with those on the list'. ${ }^{23}$ Appearing on such a list mainly applies to business, research, gender, and HIV/AIDS NGOs that offer technical expertise and social services in areas where SADC lacks competence. These CSOs are generally much more included in various SADC institutions than CSOs with a different take on regional integration that relates trade to, for example, labour rights, informal trade, social justice, and poverty. These latter CSOsare much more marginalized in SADC-led regional governance.

Those CSOs that attempt to solve problems within the neoliberal regional framework, for example facilitating the movements of goods in the region, are the most welcomed by SADC. Two important examples are the SADC Employers Group (SEG), a network of 11 national employers' organizations in southern Africa, with headquarters in South Africa; and the Association of SADC Chambers of Commerce and Industry (ASCCI), a non-profit, private sector regional network based in Botswana. On paper at least, the same applies to those CSOs such as the SADC-CNGO that seek to make neoliberal regional governance more development oriented and 'work for the poor', albeit within the market-oriented agenda. In fact, SADC-CNGO is sometimes referred to as 'the civil society alibi for SADC'. ${ }^{24}$ However, SADC-CNGO is increasingly marginalized in SADC due to its evolving critical approach, in addition to its lack of knowledge and weak moral authority discussed earlier. While aligning itself with the SADC neoliberal agenda, in recent years SADC-CNGO has also broadened its concept of trade integration to include social aspects and moved towards the more radical SAPSN-agenda. For example, in the Civil Society Forum Declaration in South Africa in2013, 
it was noted that SADC needs to move away from the current neo-liberal paradigm, focusing on free trade, market orientation and business investment, which is not appropriate for addressing the developmental challenges of the region and direct harmful to the people living there (SADC-CNGO, 2013). In fact, SADC interest in collaborating with CSOs such as SADC-CNGO is shallow and exists provided that they do not mount too much critique and, as one commentator puts it, 'rock the boat', ${ }^{25}$ but instead align themselves with the interests of SADC. Hence, even though SADC allows SADC-CNGO to come to some of its meetings, it is expected to be compliant with the SADC agenda. These critical comments raise serious concerns about the autonomy of SADC-CNGO and the risk of being co-opted by regional policy-makers such as SADC.

By the same token, those CSOs seeking critical policy reform, for example SAPSN which contests the current neoliberal trade agenda altogether, are effectively excluded in SADC. In the Peoples' Declaration from the Peoples' Summit in Windhoek 2010, all free trade arrangements were rejected (SAPSN, 2010) and in the Declaration from 2014 SADC member states are criticized for failing to guarantee access to nutritious food and essential social services and urged to protect the people of the region instead of corporate and elite interests (SAPSN 2014a). The radical standpoint of SAPSN makes SADC unwilling to respond to its critique. Because of the SADC suspicion towards SAPSN, it is claimed, SAPSN is barred from openly presenting communiqués to the SADC Summit and obstructed to organize peaceful marches (SAPSN 2014b). Also, SADC leaders are often invited to attend the Peoples' Summit but never show up (EJN, 2010). Furthermore, due to their critical agenda, SAPSN, as a representative of social movements in the region, has not been invited to be a member of the steering committee of the so-called Regional Poverty Observatory, ${ }^{26}$ a SADC-led platform which facilitates regional state-donor-civil society cooperation around poverty and development issues. Contesting the very neoliberal foundation upon which the present SADC-led regional integration project is built, SAPSN has a hard time to present its views directly to SADC and have influence on the content of various SADC policy documents. According to a representative of the SADC Directorate for Trade, Industry, Finance, Mining and Investment (TIFI), '... in a nutshell we have a particular constituency of civil society we deal with, mainly the people that do the import and export of goods are our focus. We don't deal with the pressure groups'. ${ }^{27}$ This is unfortunate since agents of civil society resisting regional governance, such as SAPSN, are needed to fill a vacuum created by the absence of real alternatives to state-led, neoliberal regionalisms. However, it should be noted that the tense relations between SADC and SAPSN seem to ease up. In May 2014 the SADC Secretariat met with a SAPSN-delegation for the first time and in order to establish more formal ties a MoU between the two is in the making. By this, SAPSN hopes to become more involved in regional policy processes (SAPSN 2014c). It remains to be seen to what extent SADC is willing to incorporate SAPSN's demands.

In terms of GL, their participation in regional governance can partly be explained by the fact that gender equality and improvement of women's rights are not direct threats to the regional capitalist order and can therefore be integrated in SADC's now-liberal agenda. Also, the use of a professional-technical approach to social change, in which gender mainstreaming is one good example, does not challenge the dominant patriarchal and capitalist values in SADC member states. Hence, SADC is not threatened on an ideological level by NGOs such as GL, which are 'safe' to include in policy talks. GL's professional-technical methods have indeed been questioned in terms of the long-term impact on the situation of women in the region. GL's work is criticized for depoliticizing the issue and being ineffective in bringing about changes on an ideological level (Geertsema, 2010). 


\section{Conclusion}

This article has shown that, contrary to the claims of previous studies on civil society regionalization in southern Africa, CSOs can be quite active players in regional governance. In fact, regional civil society advocacy in southern Africa is picking up momentum, and SADC is a much more frequent target of various regional campaigns today compared with, say, ten years ago. Some CSOs are not as powerless in SADC as previously perceived. As this article has demonstrated, one important prerequisite for gaining regional policy influence is the strategic production of knowledge and information. The adoption of the Gender Protocol, much due to GL's sophisticated advocacy methods, is a telling example.

However, these capacities are unevenly distributed among CSOs, which reflects the heterogeneous nature of regional civil society. SADC-CNGO and SAPSN struggle to underpin their advocacy claims with well-informed arguments. This differs from GL, which is considered an expert in its field, admittedly a narrower field. In addition, the three CSOs examined in this article communicate specific policy proposals, as well as demands for a just social order, very differently with regional policy-makers. SADC-CNGO indeed links up with the SADC agenda, a prerequisite to get SADC's attention, but on the whole lacks the ability to frame policy proposals in morally convincing arguments. All this makes the network rather side-lined in regional governance. On the other hand, moralizing regional politics in terms of mocking SADC leaders for taking side with business at the expense of poor people, SAPSN takes the shaming strategy too far. Its provocative language and framing of SADC as an 'enemy' that should be resisted makes the network marginalized, even if this marginalisation might be reduced considering the SAPSN visit to the SADC Secretariat in 2014. By contrast, GL is a successful civil society player in regional governance partly because it has developed a much more strategic and morally convincing way of communicating its demands. The example from southern African shows that the social constructivist claim that transnational and globally-oriented civil society actors can influence state policy by using various nonmaterial resources (e.g. Keck \& Sikkink, 1998) also applies to the regional level. In that way, the article has contributed to the understanding of regional civil society advocacy.

The empirical results of this article also have important implications for the study of regional governance. In order to examine and assess the role and success of CSOs in regional governance, it is indeed important to analyse the mechanisms behind regional intergovernmental organizations' domination of regional civil society. This article has shown that gaining influence in regional policy-making is a power game. Those actors more attuned to the neoliberal agenda, using accepted professional-technical methods in their work, have a much greater chance of being accepted as partners in regional governance than more critical actors. At the same time, using good arguments can most probably increase the chances of CSOs to gain regional policy influence, regardless of ideological proximity to regional policymakers. Considering the possibility for CSOs to be included in regional policy-making, a new, more participatory, more democratic form of regional governance in Southern Africa can be in the making.

\section{References}

Afadameh-Adeyemi, A. \& Kalula, E. (2011). SADC at 30: Re-examining the legal and institutional anatomy of the Southern African Development Community. In A. Bösl, A. du Pisani, G. Erasmus, T. Hartzenberg \& R. Sandrey (eds.), Monitoring regional integration in southern Africa yearbook. Vol. 10 (pp. 5-22). Stellenbosch: Trade Law Centre for Southern Africa. 
Armstrong, D. \& Gilson, J. (2011). Introduction. In D. Armstrong, V. Bello, J. Gilson \& D. Spini (eds.), Civil society and international governance- The role of non-state actors in global and regional regulatory frameworks (pp. 1-12). London: Routledge.

Blaauw, L. (2007). Transcending state-centrism: New regionalism and the future of southern african regional integration, $\mathrm{PhD}$-thesis, Grahamstown: Rhodes University. [Online]. Available at: http://eprints.ru.ac.za/1355/1/blaauwfinaldissertation.pdf [accessed: 25 October 2012].

Chandler, D. (2004). Constructing global civil society: morality and power in international relations. Basingstoke: Palgrave Macmillan.

Dagnino, E. (2011). Civil society in Latin America. In M. Edwards (ed.), The Oxford handbook of civil society (pp. 122-133). Oxford: Oxford University Press.

Debusscher, P. \& Hulse, M. (2014). Including Women's voices? Gender mainstreaming in EU and SADC development strategies for Southern Africa. Journal of Southern African Studies, 40, 559-573.

Dibie, R. A. (2008). Introduction: NGOs and human development in Africa: Theory and model for collaboration. In R. A. Dibie (ed.), Non-governmental organizations (NGOs) and sustainable development in Sub-Saharan Africa (pp. 1-26). Lanham, MD: Lexington Books.

Edwards, M. (2009). Civil society. Cambridge: Polity Press.

Farrell, M. (2005). The global politics of regionalism: An introduction. In M. Farrell, B. Hettne \& L. Van Langenhove (eds), Global politics of regionalism (pp. 1-17). London: Pluto Press.

Fawcett, L. \& Hurrell. A. (eds.). (1995). Regionalism in world politics. New York: Oxford University Press.

FDC. (2007). Mozambican civil society within: Evaluation, challenges, opportunities and action. Maputo: FDC. [Online]. Available at:

http://www.civicus.org/media/CSI_Mozambique_Country_Report.pdf [accessed: 25 October 2012].

Fogarty, E. (2014). States, nonstate actors, and global governance. London: Routledge.

Gamson, W. A. (1995). Constructing social protest. In H. Johnston \& B. Klandermans (eds), Social movements and culture (pp. 85-106). Minneapolis: University of Minnesota Press.

Geertsema, M. (2010). Challenging the lion in its den: Dilemmas of gender and media activism in South Africa. African Journalism Studies, 31 (1), 68-88.

Gender Links. (2009). Roadmap to equality. Johannesburg: Gender Links

Gender Links. (2013). SADC Gender Protocol Barometer 2013. Johannesburg: Gender Links.

Gender Links. (2014). Annual report 2013/2014. Johannesburg: Gender Links.

Gilson, J. (2011). Governance and non-governmental organizations in East Asia. In D. Armstrong, V. Bello, J. Gilson \& D. Spini (eds.), Civil society and international governance (pp. 129-147). New York: Routledge.

Godsäter, A. 2013. Regional environmental governance in the Lake Victoria Region: Rhe role of civil society. African Studies, 72 (1), 64-85.

Grugel, J. (2006). Regionalist governance and transnational collective action in Latin America. Economy and Society, 35, 209-231.

Harrison, G. (2010). Neo-liberal Africa. London: Zed Books.

Hettne, B. (2005). Beyond the 'new' regionalism. New Political Economy, 10, 543-571.

Hinds, K. (2008). Civil society regionalisation and access to policy space: The case of CARICOM. International Studies Association's 49 ${ }^{\text {th }}$ Annual Convention, San Francisco, USA, 26-29 March 2008. 
Igarashi, S. (2011). The new regional order and transnational civil society in Southeast Asia. World Political Science Review, 7(1), 1-31.

Jönsson, C \& Tallberg, J. (2010). Transnational actors in global governance. New York: Palgrave Macmillan.

Kaldor, M. (2003). Global civil society: an answer to war. Cambridge, UK; Malden, MA: Polity Press.

Kanyenze, G., Kondo, T. \& Martens, J. (2006). The search for sustainable, human development in Southern Africa. Harare: ANSA.

Katz, H. (2006). Gramsci, hegemony, and global civil society networks. Voluntas, 17, 333348.

Keck, M. E., \& Sikkink, K. (1998). Activists beyond borders: advocacy networks in international politics. Ithaca, N.Y.: Cornell University Press

Kimani, N. (2007). Reinvention of environmental governance in East Africa: Explanatory and normative dimensions. $\mathrm{PhD}$-thesis. Australian National University

Korey, W. (1999). Human rights NGOs: The power of persuasion. Ethics \& International Affairs, 13(1), 151-174.

Landsberg, C. (2012). The Southern African Development Community's decision-making architecture. In C. Saunders, G. A. Dzinesa \& D. Nagar (eds), Region-building in Southern Africa: Progress, problems and prospects (pp. 63-77). London: Zed Books.

Matlosa, K. (2006). The role of political parties in regional integration in the SADC Region. In A. Bösl, W. Breytenbach, T. Hartzenberg, C. McCarthy \& K. Schade (eds.), Monitoring regional integration in Southern Africa yearbook. Vol. 6 (pp. 116-139). Stellenbosch: Trade Law Centre for Southern Africa.

Matlosa, K \& Lotshwao, K. (2010). Political integration and democratisation in Southern Africa: Progress, problems and prospects. Johannesburg: EISA.

Michael, S. (2004). Undermining development: the absence of power among local NGOs in Africa. Oxford: James Currey.

Mukute, M. \& Taylor, J. (2013). Struggles for systems that nourish: Southern African civil society contributions and challenges to the creation of flourishing societies. Development in Practice, 23, 609-616.

Muukkonen, M. (2009). Framing the field: Civil society and related concepts. Nonprofit and Voluntary Sector Quarterly, 38, 684-700.

Ndumbro, L \& Kiondo, A. (2007). The third sector in Tanzania- Learning more about civil society organisations, their capabilities and challenges. London: Aga Khan Development Network. [Online]. Available at: http://www.akdn.org/publications/civil_society_tanzania_third_sector.pdf [accessed: 25 October 2012].

Obadare, E. (2011). Civil society in Sub-Saharan Africa. In M. Edwards (ed), The Oxford Handbook of Civil Society (pp. 183-194). Oxford: Oxford University Press.

Opoku-Mensah. P. (2008). The state of civil society in Sub-Saharan Africa. In V. Finn Heinrich \& L. Fioramonti (eds.). CIVICUS Global Survey of the State of Civil SocietyVolume 2 (pp. 75-90). Bloomfield: Kumarian Press

Peters, C. (2011). Is SADC losing track? In A. Bösl, A. du Pisani, G. Erasmus, T. Hartzenberg \& R. Sandrey (eds.), Monitoring Regional Integration in Southern Africa Yearbook. Vol. 10 (pp. 143-168). Stellenbosch: Trade Law Centre for Southern Africa.

Peters-Berries, C. (2010). Regional integration in southern Africa- A guidebook. Bonn: InWEnt.

Pressend, M. (2010). 30 years of the Southern African Development Community: What's to celebrate? [Online: The South African Civil Society Information Service]. Available at: http://sacsis.org.za/site/article/536.1 [accessed: 12 September 2012]. 
Ranchod, K. (2007). State-civil society relations in South Africa: Some lessons from engagement. Policy: Issues \& Actors, 20(7), 1-23.

Reuter, M. (2007). Networking a region into existence? Dynamics of civil society regionalization in the Baltic Sea area. Berlin: Berliner Wissenschafts Verlag.

Risse, T. (2002). Transnational actors and world politics. In W. Carlsnaes, T. Risse \& B. Simmons (eds), Handbook of International Relations (pp. 255-274). London: SAGE

Risse, T. (2004). Global governance and communicative action. Government and Opposition, 39, 288-313.

Sachikonye, L. M. (2007). Consolidating democratic governance in southern Africa: Zimbabwe, EISA Research Report No. 30. Johannesburg: EISA.

SADC-CNGO. (2003). Memorandum of understanding on general co-operation between $S A D C$ and $S A D C-C N G O$. Gaborone: SADC-CNGO.

SADC-CNGO. (2009). Strategic plan 2010-2014. Gabarone: SADC-CNGO

SADC-CNGO. (2010). Report of the Post Forum Feedback Meeting for Civil Society in Namibia, Safari Hotel, Windhoek Namibia, 5 October 2010. Gaborone: SADCCNGO. [Online]. Available at: http://www.sadccngo.org/forums.php?showid=75\&lang=0\&PHPSESSID=5tqop74qpf 1q9f1t4sasab8sg5 [accessed 13 July 2012].

SADC-CNGO. (2011). Civil society statement: 7th Southern Africa Civil Society Forum. Gaborone: SADC-CNGO. [Online]. Available at: http://www.csoeffectiveness.org/IMG/pdf/7thcsfdeclaration_2_.pdf [accessed: 13 July 2012].

SADC-CNGO. (2013). $9^{\text {th }}$ Southern Africa Civil Society Forum. Gaborone: SADC-CNGO. [Online]. Available at: http://www.sadccngo.org/wp-content/uploads/2013/09/9thCSF-Statement-1489F56.pdf [accessed: 25 February 2015].

Saguier, M. (2011). Transnational labour mobilization in the Americas. In D.

Armstrong, V. Bello, J. Gilson \& D. Spini (eds.), Civil Society and International

Governance (pp. 181-197). New York: Routledge.

Salamon, L. M., Sokolowski, S. W., \& Associates. (2004). Global civil society. Vol. 2, Dimensions of the non-profit sector. London: Kumarian Press.

SAPSN. (2009). The 2009 SADC People's Summit Report. Lilongwe: SAPSN

SAPSN. (2010). SADC Peoples' Summit Declaration (Windhoek, Namibia, August 2010). Lilongwe: SAPSN [Online]. Available at: http://www.alternativeregionalisms.org/? $\mathrm{p}=4521$ [accessed: 30 August 2012].

SAPSN. (2014a). SADC People's Summit, 15-16 August 2014, The Bulawayo Communique. Lilongwe: SAPSN. [Online]. Available at: http://www.esaff.org/images/sadc_people_s_summit_2014__pdf.pdf [accessed: 25 February 2015].

SAPSN. (2014b). SAPSN rolls mining training and meets SADC secretariat. Lilongwe: SAPSN. [Online]. Available at: http://sadcpeoplessummit.org/2014/05/21/sapsn-rollsmining-training-and-meets-sadc-secretariat/\#more-1548 [accessed: 25 February 2015].

SAPSN. (2014c). More Positivity after SADC-SAPSN Secretariat's meeting. Lilongwe: SAPSN. [Online]. Available at: http://sadcpeoplessummit.org/2014/07/14/morepositivity-after-sadc-sapsn-secretariats-meeting [accessed: 25 February 2015].

Scholte, J. A. (2005). Globalization- a critical introduction. Basingstoke: Palgrave.

Scholte, J. A. (2011). (ed.). Building global democracy? Civil society and accountable global governance. Cambridge: Cambridge University Press

Söderbaum, F. (2004). Modes of regional governance in Africa: Neo-liberalism, sovereignty boosting, and shadow networks. Global Governance, 10, 419-436.

Söderbaum, F. (2007). Regionalisation and civil society: The case of Southern Africa. New Political Economy, 12, 319-337. 
Söderbaum, F. \& Taylor, I. (2008). Considering micro-regionalism in Africa in the twentyfirst ventury. In F. Söderbaum and I. Taylor (eds.), Afro-Regions: the Dynamics of Cross-border Micro-regionalism in Africa (pp. 13-31). Uppsala: the Nordic Africa Institute

Tallberg, J., Sommerer, T., Squatrito, T. \& Jönsson, C. (2013). The opening up of international organizations. Cambridge: Cambridge University Press.

Tandon, R. \& Kak, M. (2008). The effects of rapid socioeconomic growth on civic activism in emerging democracies: An analysis of civil society in the Asia-Pacific region. In V. F. Heinrich \& L. Fioramonti (eds), CIVICUS global survey of the state of civil societyVolume 2 (pp. 91-109). Bloomfield: Kumarian Press.

Tsie, B. (2001). International political economy and Southern Africa. In P. Vale, L. Swatuk

\& B. Odén (eds.), Theory, change and Southern Africa's future (pp. 111-147). Basingstoke, Palgrave.

Van der Vleuten, A. \& Hulse, M. (2013). Governance transfer by the Southern African Development Community (SADC). SFB-Governance Working Paper Series No. 48. Berlin: DFG Collaborative Research Center.

Van Langenhove, L. (2011). Building regions - The regionalization of the world order. Farnham: Ashgate.

Van Rooy. A. (2004). The global legitimacy game. Basingstoke: Palgrave

Zongwe, D. (2008). Gender equality and harmful practices in the SADC Gender Protocol. The Current, 12(1), 99-121.

\section{Endnotes}

\footnotetext{
${ }^{1}$ The most comprehensive understanding of southern Africa covers the SADC area, i.e. Angola, Botswana, the DRC, Lesotho, Madagascar, Malawi, Mauritius, Mozambique, Namibia, Seychelles, South Africa, Swaziland, Tanzania, Zambia and Zimbabwe, but there are also other informal and dynamic sub-regions within this definition.

${ }^{2}$ The bulk of the empirical data stems from 18 interviews which were conducted in 2008 and 2009 with representatives from CSOs, SADC Secretariat, donors and research institutes, as well as various CSO documents.

${ }^{3}$ The role of foreign donors in civil society regionalization is also important, but beyond the scope of this article. ${ }^{4}$ e.g. interview with Professor Bertha Osei-Hwedie, University of Botswana, 5 December 2008; interview with Professor Garth le Pere, University of Pretoria, formerly Institute for Global Dialogue (IGD), 27 November 2008; interview with Brian Ashley, Alternative Information and Development Center (AIDC), 17 December 2009; Landsberg 2012; SADC-CNGO 2009.

${ }^{5}$ Interview with Neville Gabriel, formerly Southern Africa Trust, 2 December 2008; interview with Jacob Mati, formerly CIVICUS World Alliance for Citizen Participation, 27 November 2009; interview with Samantha Yates, formerly UK Department for International Development , 14 December 2009; interview with Jennifer Chiriga, formerly African Forum and Network on Debt and Development (AFRODAD), 2 December 2009; interview with Janah Ncube, formerly SADC Directorate for Policy, Planning and Resource Mobilization, 8 December 2008.

${ }^{6}$ Interview with Jennifer Chiriga, formerly Southern Africa Trust, 2 December 2008.

${ }^{7}$ Interview with Professor Bertha Osei-Hwedie, University of Botswana, 5 December, 2008.

${ }^{8}$ Interview with Bob Muchabaiwa, SADC-CNGO, 7 December 2009.

${ }^{9}$ Interview with Jana Ncube, formerly SADC Directorate for Policy, Planning and Resource Mobilization, 8 December 2008.
} 
${ }^{10}$ Interview with Neville Gabriel, formerly Southern Africa Trust, 2 December 2008.

${ }^{11}$ Interview with Jacob Mati, formerly CIVICUS, 27 November 2009.

${ }^{12}$ Interview with Dr. Michel Pressend, formerly IGD, 27 November 2008.

${ }^{13}$ Interview with Janah Ncube, formerly SADC Directorate for Policy, Planning and Resource Mobilization, 8 December 2008.

${ }^{14}$ Interview with Professor Patrick Bond, University of Kwa-Zulu Natal, 14 December 2008.

${ }^{15}$ Interview with Dakarayi Matanga, Zimbabwe Coalition on Debt and Development (ZIMCODD), 4

December 2009.

${ }^{16}$ Interview with Susan Tolmay, Gender Links, 27 November 2009.

${ }^{17}$ Interview with Janah Ncube, formerly SADC Directorate for Policy, Planning and Resource Mobilization, 8 December 2008.

${ }^{18}$ Interview with Magdeline Mathiba-Madibela, SADC Gender Unit, 11 December 2009.

${ }^{19}$ Interview with Simon Vilakazi, Economic Justice Network (EJN), 15 December 2009.

${ }^{20}$ Interview with Bob Muchabaiwa, SADC-CNGO, 7 December 2009.

${ }^{21}$ Interview with Patricia Kasiamhuru, SAPSN, 2 December 2009.

${ }^{22}$ Interview with Janah Ncube, formerly SADC Directorate for Policy, Planning and Resource Mobilization, 8 December 2008.

${ }^{23}$ Interview with Janah Ncube, formerly SADC Directorate for Policy, Planning and Resource Mobilization, 8 December 2008

${ }^{24}$ Interview with Professor Garth le Pere, University of Pretoria, formerly IGD, 27 November 2008.

${ }^{25}$ Interview with Professor Garth le Pere, University of Pretoria, formerly IGD, 27 November 2008.

${ }^{26}$ E-mail communication with Malcolm Damon, EJN, 20 August 2012.

${ }^{27}$ Interview with Happias Kuzvinzwa, SADC Directorate for Trade, Industry, Finance, Mining and Investment , 11 December 2009. 